\title{
Multispecies Allometric Models Predict Grass Biomass in Semidesert Rangeland
}

\author{
Aleta M. Nafus, ${ }^{1}$ Mitchel P. McClaran, ${ }^{2}$ Steven R. Archer, ${ }^{2}$ and Heather L. Throop ${ }^{3}$ \\ Authors are ${ }^{1}$ Rangeland Technician, US Department of Agriculture-Agricultural Research Service, Eastern Oregon Agricultural Research Center, 67826- \\ A Highway 205, Burns, OR 97720, USA; ${ }^{2}$ Professors, School of Natural Resources, University of Arizona, 325 Biological Sciences East, Tucson, AZ \\ 85721, USA; and ${ }^{3}$ Assistant Professor, Department of Biology, New Mexico State University, Las Cruces, NM 88003, USA.
}

\begin{abstract}
Multispecies allometric models to predict grass biomass may increase field study efficiency by eliminating the need for speciesspecific data. We used field measurements during two growing seasons to develop single-species and multispecies regression models predicting the current year's aboveground biomass for eight common cespitose grass species. Simple and stepwise regression analyses were based on natural log expressions of biomass, basal diameter, and height, and a dummy variable expression of grazing history. Basal diameter had the strongest relationship with biomass among single-species (adjusted $R^{2}=0.80$ to 0.91 ) and multispecies (adjusted $\left.R^{2}=0.85\right)$ models. Regression slopes $(b)$ for diameter among single-species $(b=1.01$ to 1.49$)$ and the multispecies $(b=1.25)$ models suggests that biomass will double when diameter increases $\sim 75 \%$. Height and grazing history added little predictive value when diameter was already in the model. When applied to actual populations, biomass estimates from multispecies models were within 3-29\% of estimates from the single-species models. Although the multispecies biomass-size relationship was robust across the cespitose life-form, users should be cautious about applying our equations to different locations, plant sizes, and population size-structures.
\end{abstract}

\section{Resumen}

Los modelos alométricos de especies múltiples para predecir biomasa en gramíneas pueden incrementar la eficiencia del estudio en campo, eliminando la necesidad de datos propios de cada especie. Se utilizaron medidas en el terreno durante dos estaciones de crecimiento para desarrollar modelos de regresión simple y de especies múltiples para predecir la biomasa aérea del presente año en ocho especies de gramíneas cespitosas. Los análisis de regresión simple y regresión gradual se basaron en expresiones logarítmicas naturales de la biomasa, diámetro basal y altura; y una expresión simulada del pastoreo histórico. El diámetro basal mostró la relación más alta con biomasa entre los modelos simple $\left(R^{2}\right.$ ajustada $\left.=0.80-0.91\right)$ y de especies múltiples $\left(R^{2}\right.$ ajustada $=0.85)$. La pendiente de la regresión $(b)$ para el diámetro entre los modelos simple $(b=1.01-1.49)$ y de especies múltiples $(b=1.25)$ sugieren que la biomasa será el doble cuando el diámetro se incremente aproximadamente $75 \%$. La altura de la planta y la historia del pastoreo no fueron determinantes cuando el diámetro se incluyó en el modelo. Cuando se aplicaron a poblaciones reales, las estimaciones de biomasa de modelos de especies múltiples estuvieron dentro de un 3 y $29 \%$ de las estimaciones de los modelos simples. Aunque la relación biomasa-tamaño del modelo de especies múltiples fue alta entre la forma cespitosa, se debe ser cauteloso en la aplicación de estas ecuaciones en las diferentes localidades, tamaños de planta y tamaño de la estructura de la población.

Key Words: allometry, basal diameter, grazing history, plant height, regression analysis

\section{INTRODUCTION}

Aboveground net primary productivity (ANPP) is a useful synthetic indicator of grass response to shrub encroachment, climate change, and activities such as livestock grazing and fire; and peak current year's biomass is often used to estimate grass ANPP (Scurlock et al. 2002). Directly measuring biomass (harvesting and weighing) is accurate but destructive and time consuming. An indirect estimate based on allometric relation-

Research was funded in part by the US Dept of Agriculture-National Research Initiativemanaged ecosystems grant 2005-35101-15408 and by the Arizona Agricultural Experiment Station projects AZRT-139021 and AZRT-136711

At the time of the research, Nafus was a Graduate Research Assistant, School of Natural Resources, University of Arizona, Tucson, AZ 85721, USA.

Correspondence: Mitchel McClaran, School of Natural Resources, University of Arizona, 325 Biological Sciences East, Tucson, AZ 85721, USA. Email: mcclaran@u.arizona.edu

Manuscript received 8 January 2008; manuscript accepted 17 October 2008. ships is a nondestructive and time-efficient alternative, if accuracy is not compromised (Sala and Austin 2000).

Allometric models are based on correlations between biomass and morphological characters, such as basal diameter (or area), height, canopy diameter, or canopy volume. They have been used to estimate biomass of trees and shrubs (Ares and Fownes 2000; Northup et al. 2005). When used for grasses, basal diameter is typically the best single predictor of current year's biomass for cespitose grasses; although height alone is a poorer predictor, the addition of height may improve predictions for models already containing basal diameter (Andariese and Covington 1986; Johnson et al. 1988; Assaeed 1997; Guevara et al. 2002).

General models representing multiple species, land uses, and locations can eliminate the investment needed to develop many specific models (Lambert et al. 2005). Multispecies and multilocation models have been moderately successful for trees and shrubs (Singh 1986; Buech and Rugg 1989; Jenkins et al. 2003; Lambert et al. 2005). Multispecies models have not been evaluated 
for grasses, but Andariese and Covington (1986) rejected multisite (contrasting fire histories) models for three grass species. For grasses, interspecific variation in the biomass-size relationship caused by repeated defoliation may make it difficult to generalize across sites with different grazing histories (Peterson 1962; Trlica and Orodho 1989; Kotanen and Bergelson 2000).

We evaluated multispecies allometric models to predict the current year's biomass for eight grass species common in semidesert rangelands of the southwestern United States. We focused on 1) strength $\left(R^{2}\right)$ and slope (b) of models, 2 ) influence of each species on multispecies models, 3 ) influence of grazing history, and 4) predictions of biomass for actual populations.

\section{METHODS}

\section{Study Area}

We performed field measurements from 4 September 2005 to 17 September 2005 and from 10 September 2006 to 30 September 2006, during peak biomass (based on completeness of seed set and leaf expansion) within the 2.7-ha Rodent Station (ungrazed since 1903) and the contiguous grazed area on the Santa Rita Experimental Range, $60 \mathrm{~km}$ south of Tucson, Arizona, at the $1030-\mathrm{m}$ elevation. Grass production is strongly related to summer (June-September) precipitation at this site (Cable 1975), where the long-term (1922-2006) summer average is $207 \mathrm{~mm}$, but $163 \mathrm{~mm}, 204 \mathrm{~mm}$, and $283 \mathrm{~mm}$ occurred in 2004, 2005 , and 2006, respectively. Mean annual temperature is $\sim 18^{\circ} \mathrm{C}$. Soils are coarse-loamy, mixed, superactive, monacid, thermic Ustic Torrifluvents in the Combate series (Breckenfeld and Robinett 2003). Vegetation is mesquite (Prosopis velutina Woot.) savanna, with a $25-40 \%$ canopy cover of mesquite $1-5$ $\mathrm{m}$ tall and a $2-5 \%$ basal cover of $\mathrm{C}_{4}$ grasses (McClaran and Angell 2006). Average cattle stocking rates (0.03 animals $\mathrm{ha}^{-1} \cdot \mathrm{yr}^{-1}$ ) under a seasonal rotation since 1973 resulted in $\sim 50 \%$ use of perennial grasses (Mashiri et al. 2008), but cattle were not present in the study area in 2005 or 2006.

\section{Grass Biomass}

For each species, we selected plants to create a continuous distribution of basal diameters encompassing the available range of sizes. Species and ranges of diameters were black grama (Bouteloua eriopoda [Torr.] Torr.), 0.14-9.1 cm; cottontop (Digitaria californica [Benth.] Henr.), 0.23-12.0 cm; Boer's lovegrass (Eragrostis curvula [Schrad.] Nees), 0.11-16.5 cm; Lehmann's lovegrass (Eragrostis lehmanniana Nees), 0.05$5.2 \mathrm{~cm}$; tanglehead (Heteropogon contortus [L.] Beauv. ex Roemer \& J.A. Schultes), 0.16-15.0 cm; bush muhly (Mublenbergia porteri Scribn. ex Beal), 0.15-9.1 cm; plains bristlegrass (Setaria leucopila [Scribn. \& Merr.] K. Schum.), 0.16-5.9 cm; and threeawns (Aristida spp. combined Aristida glabrata [Vasey] Hitchc., Aristida hamulosa Henr., and Aristida ternipes Cav. because of identification difficulties), 0.05-5.8 cm. Grasses are cespitose, except for black grama, which grows as discrete cespitose-like ramets connected by stolons.

We typically collected 15 plants of each species from both grazed and ungrazed areas each year. Exceptions were black grama $(n=25)$, which was collected from ungrazed areas in both years because it was absent from the grazed area, and tanglehead
(2005: $n=25$; and 2006: $n=15$ ), which was from grazed areas in 2005 and from both grazed and ungrazed areas in 2006.

\section{Morphological Measures}

We measured basal diameter with a diameter tape $(0.1-\mathrm{cm}$ increments) on large plants $(>0.35 \mathrm{~cm})$ and with digital calipers (0.1-mm increments, average of two orthogonal measures) for smaller plants. We measured plant height $(0.5-\mathrm{cm}$ increments) from ground to the uppermost leaf collar. For bush muhly (spherical growth) and black grama (prostrate growth), we measured average height. After measurements, we harvested plants from $1 \mathrm{~cm}$ above ground (including half the connecting stolon for black grama) and dried it at $60^{\circ} \mathrm{C}$. We removed the previous years' biomass, redried the plants $\left(60^{\circ} \mathrm{C}\right.$ for $\left.48 \mathrm{~h}\right)$, and weighed (0.1-g increments) the current year's biomass.

\section{Allometric Models}

We used natural $\log (\ln )$ transformations of biomass and size to represent the curvilinear (geometrically scaled) biomass-size relationship. Our $\ln y=a+b(\ln x)$ detransforms to $y=e^{a} x^{b}$, which is a slight variation on the typical power function $(y=$ $a x^{b}$ ) for allometric relationships (Andariese and Covington 1986; Gayon 2000; Northup et al. 2005). The response variable was plant biomass: $Y=$ current year's biomass $[\ln (\mathrm{g}$. plant $\left.\left.{ }^{-1}\right)\right]$. Explanatory variables were basal diameter $\left[X_{D}\right.$, $\ln (\mathrm{cm})]$, height $\left[X_{H}, \ln (\mathrm{cm})\right]$, and grazing history $\left(X_{G}\right.$; ungrazed $=0$ and grazed $=1$ ). We did not correct for logarithmic bias (Baskerville 1972).

We used simple and stepwise $(P<0.05$ to enter in fit-model command in JMP software, Release 5.1; Sall et al. 2005) regression to predict biomass for each species separately (single species) and for all species combined (multispecies) using data pooled from 2005 and 2006. $X_{G}$ was not included in the stepwise procedure for black grama or tanglehead because of insufficient data.

We evaluated the effect of any single species on multispecies models by systematically excluding data for one species from the multispecies model, then predicting biomass for the excluded species $\left(\bar{y}_{\text {ind }}\right)$ with the resulting multispecies model. We compared the adjusted $R^{2}$ derived from the full (eight species) multispecies model $\left(R_{\text {full }}^{2}\right)$ and the seven species models $\left(R^{2}\right.$ ind $)$ for each species. Excluded species had an influence on the full multispecies model if $R_{\text {full }}^{2} \neq R_{\text {ind }}^{2}$.

\section{Models Applied to Actual Populations}

We compared estimates of biomass $\left(\mathrm{g} \cdot \mathrm{m}^{-2}\right)$ between singlespecies and multispecies models (using $X_{D}$ and $X_{D}+X_{H}$ models) for populations of four species. In 2005 and 2006, we measured diameter and height of all cottontop, Lehmann's lovegrass, bush muhly, and plains bristlegrass plants in 10 intershrub areas (2.25-m radius and $>5 \mathrm{~m}$ from mesquite canopy; $n=5$ each in grazed and ungrazed areas) and under 9 mesquite $(2.35-4.08-\mathrm{m}$ canopy radius; $n=4$ in grazed area, and $n=5$ in ungrazed area). We estimated biomass of each plant using single-species and multispecies models and summed those values across the population to represent total biomass per area $\left(\mathrm{g} \cdot \mathrm{m}^{-2}\right)$. We examined the influence of population size and structure on biomass estimates because they changed between 2005 and 2006. Population sizes (N) increased from 2005 to 2006 but not 
Table 1. Regression intercepts, coefficients, adjusted $R^{2}$, and root mean square errors (RMSE) of natural log-transformed plant basal diameter $\left(X_{D}\right)$, plant height $\left(X_{H}\right)$, and grazing history $\left(X_{G}\right)$ for singlespecies and multispecies models to solve for the natural log of the current year's biomass $(\mathrm{g})$. Separate rows for each species and multispecies show results for unique combinations of explanatory variables $\left(X_{D}, X_{H}\right.$, and $\left.X_{G}\right)$. Empty cells occur because coefficients are listed only for explanatory variables, where the probability to enter in a stepwise procedure was $P<0.05$. The diameter-only multispecies model detransforms to biomass $(\mathrm{g})=e^{1.441} \cdot$ diameter $(\mathrm{cm})^{1.253}$.

\begin{tabular}{|c|c|c|c|c|c|c|c|}
\hline \multirow[b]{2}{*}{ Species } & \multirow[b]{2}{*}{$n$} & \multirow[b]{2}{*}{ Intercept } & \multicolumn{3}{|c|}{ Coefficients } & \multirow{2}{*}{\multicolumn{2}{|c|}{ Adj. $R^{2} \mathrm{RMSE}$}} \\
\hline & & & $X_{D}$ & $X_{H}$ & $X_{G}$ & & \\
\hline \multirow[t]{3}{*}{ Threeawns } & 79 & 1.418 & 1.303 & - & - & 0.81 & 0.66 \\
\hline & & -7.665 & - & 2.852 & - & 0.58 & 0.77 \\
\hline & & -2.109 & 1.018 & 1.096 & - & 0.86 & 0.57 \\
\hline \multirow[t]{3}{*}{ Black grama } & 54 & 0.903 & 1.220 & - & - & 0.80 & 0.69 \\
\hline & & -7.367 & - & 2.991 & - & 0.57 & 1.00 \\
\hline & & -1.649 & 0.995 & 0.890 & - & 0.82 & 0.65 \\
\hline \multirow[t]{3}{*}{ Cottontop } & 87 & 1.512 & 1.250 & - & - & 0.89 & 0.48 \\
\hline & & -13.183 & - & 4.085 & - & 0.71 & 0.77 \\
\hline & & -3.510 & 0.963 & 1.353 & - & 0.92 & 0.41 \\
\hline \multirow[t]{3}{*}{ Boer's lovegrass } & 76 & 1.229 & 1.087 & - & - & 0.82 & 0.60 \\
\hline & & -6.555 & - & 2.310 & - & 0.57 & 0.94 \\
\hline & & -1.205 & 0.898 & 0.680 & - & 0.84 & 0.57 \\
\hline Lehmann's & 86 & 1.721 & 1.434 & - & - & 0.90 & 0.56 \\
\hline \multirow[t]{2}{*}{ lovegrass } & & -12.466 & - & 3.845 & - & 0.71 & 0.96 \\
\hline & & -2.598 & 1.128 & 1.169 & - & 0.93 & 0.48 \\
\hline \multirow[t]{3}{*}{ Tanglehead } & 65 & 1.736 & 1.201 & - & - & 0.90 & 0.51 \\
\hline & & -10.000 & - & 3.287 & - & 0.66 & 0.94 \\
\hline & & -1.485 & 0.994 & 0.865 & - & 0.92 & 0.46 \\
\hline \multirow[t]{4}{*}{ Bush muhly } & 81 & 1.622 & 1.192 & - & - & 0.82 & 0.59 \\
\hline & & -10.994 & - & 3.921 & - & 0.62 & 0.84 \\
\hline & & -4.238 & 0.891 & 1.761 & - & 0.89 & 0.46 \\
\hline & & 1.807 & 1.197 & - & -0.364 & 0.83 & 0.56 \\
\hline \multirow[t]{4}{*}{ Plains bristlegrass } & 87 & 1.357 & 1.490 & - & - & 0.91 & 0.45 \\
\hline & & -10.623 & - & 3.282 & - & 0.72 & 0.80 \\
\hline & & -2.782 & 1.145 & 1.108 & - & 0.95 & 0.35 \\
\hline & & 1.496 & 1.498 & - & -0.291 & 0.92 & 0.90 \\
\hline \multirow[t]{3}{*}{ Multispecies model } & 615 & 1.441 & 1.253 & - & - & 0.85 & 0.63 \\
\hline & & -6.360 & - & 2.362 & - & 0.53 & 1.11 \\
\hline & & -1.212 & 1.051 & 0.760 & - & 0.88 & 0.56 \\
\hline
\end{tabular}

uniformly across plant sizes (cottontop, $N_{2005}=1128$ and $N_{2006}=1180 ; \quad$ Lehmann's lovegrass, $N_{2005}=409$ and $N_{2006}=18$ 377; bush muhly, $N_{2005}=1068$ and $N_{2006}=1183$; and plains bristlegrass, $N_{2005}=384$ and $N_{2006}=531$ ).

\section{RESULTS}

\section{Single-Species and Multispecies Models}

Among single-species models, basal diameter alone $\left(X_{D}\right)$ accounted for $80-91 \%$ of the variation in aboveground biomass, whereas height alone $\left(X_{H}\right)$ accounted for $57-72 \%$ (Table 1). Including $X_{H}$ as a second explanatory variable with $X_{D}$ added little predictive capacity (increased adjusted $R^{2}=0.02$ to $\left.0.07, P<0.05\right)$ to species-specific models.
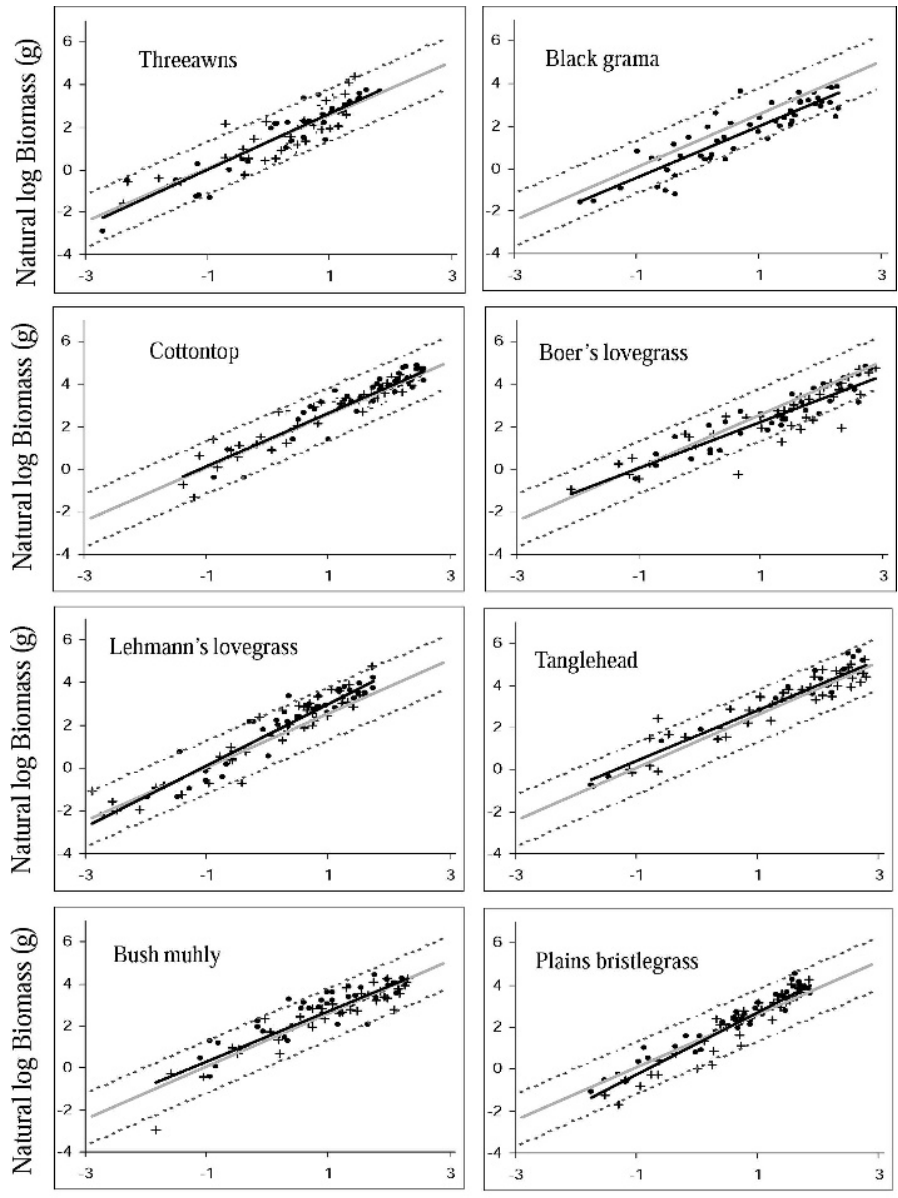

Natural log Basal Diameter (cm)

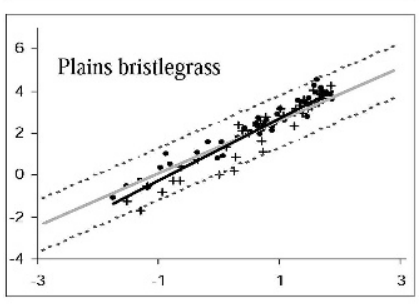

Natural $\log$ Basal Diameter (cm)

Figure 1. Multispecies model regression line (light center line) and 95\% prediction interval (dashed lines) overlaid with single-species regression lines using only diameter (dark center line) for each of the eight species (see Table 1 for equation coefficients). Dots ( $\bullet$ ) indicate ungrazed; pluses (+), grazed; and both represent values for individual plants. The diameter-only multispecies model detransforms to biomass $(\mathrm{g})=e^{1.441} \cdot$ diameter $(\mathrm{cm})^{1.253}$.

Including grazing history $\left(X_{G}\right)$ added no predictive capacity for four species and little capacity for two species (bush muhly and plains bristlegrass increased adjusted $R^{2}=0.01$, $P<0.05$ ).

For multispecies models, $X_{D}$ alone accounted for $85 \%$ of the variation in aboveground biomass, but $X_{H}$ alone accounted for $53 \%$ (Table 1). Including $X_{H}$ as a second explanatory variable added little predictive capacity (increased adjusted $R^{2}=0.03$, $P<0.05$ ), and grazing history was not included as a significant explanatory variable in the stepwise analyses. The diameter-only multispecies model detransforms to biomass $(\mathrm{g})=e^{1.441}$. diameter $(\mathrm{cm})^{1.253}$.

\section{Multispecies Model Evaluation}

Single-species models were within the $95 \%$ prediction interval of the diameter-only multispecies model (Fig. 1). There was no indication that any one species was influencing the general model parameters for either $X_{D}$ or $X_{D}+X_{H}$ regressions $\left(R_{\text {gen }}^{2}=R_{\text {ind }}^{2}\right.$ through the second decimal place). 
Table 2. Biomass predicted for actual populations of four grass species in 2005 and 2006 using the multispecies and single-species models based on diameter only and diameter + height explanatory variables. The third column in each pair is the ratio of the biomass predictions of the multispecies to single-species models.

\begin{tabular}{|c|c|c|c|c|c|c|c|}
\hline \multirow[b]{2}{*}{ Species } & \multirow[b]{2}{*}{ Year } & \multicolumn{3}{|c|}{ Diameter only } & \multicolumn{3}{|c|}{ Diameter + height } \\
\hline & & $\begin{array}{l}\text { Multispecies } \\
\left(\mathrm{g} \cdot \mathrm{m}^{-2}\right)\end{array}$ & $\begin{array}{c}\text { Single-species } \\
\left(\mathrm{g} \cdot \mathrm{m}^{-2}\right)\end{array}$ & $\begin{array}{c}\text { Multispecies to } \\
\text { single-species ratio }\end{array}$ & $\begin{array}{l}\text { Multispecies } \\
\left(\mathrm{g} \cdot \mathrm{m}^{-2}\right)\end{array}$ & $\begin{array}{c}\text { Single-species } \\
\left(\mathrm{g} \cdot \mathrm{m}^{-2}\right)\end{array}$ & $\begin{array}{c}\text { Multispecies to } \\
\text { single-species ratio }\end{array}$ \\
\hline \multirow[t]{2}{*}{ Cottontop } & 2005 & 10.3 & 11.0 & 0.93 & 10.5 & 9.6 & 1.10 \\
\hline & 2006 & 20.3 & 21.8 & 0.94 & 22.4 & 21.5 & 1.04 \\
\hline \multirow[t]{2}{*}{ Lehmann's lovegrass } & 2005 & 2.0 & 2.6 & 0.79 & 2.3 & 2.5 & 0.91 \\
\hline & 2006 & 7.3 & 7.1 & 1.03 & 8.1 & 6.5 & 1.24 \\
\hline \multirow[t]{2}{*}{ Bush muhly } & 2005 & 15.4 & 17.0 & 0.90 & 12.0 & 16.6 & 0.72 \\
\hline & 2006 & 19.1 & 20.8 & 0.92 & 13.3 & 16.4 & 0.81 \\
\hline \multirow[t]{2}{*}{ Plains bristlegrass } & 2005 & 1.6 & 1.7 & 0.93 & 1.7 & 1.4 & 1.24 \\
\hline & 2006 & 3.0 & 3.7 & 0.81 & 3.2 & 2.9 & 1.13 \\
\hline
\end{tabular}

\section{Models Applied to Actual Populations}

Multispecies model estimates of biomass for actual populations were within 3-29\% of estimates using single-species models. Across all species by year combinations, biomass estimates $\left(\mathrm{g} \cdot \mathrm{m}^{-2}\right)$ for single-species and multispecies models were more similar for the $X_{D}$ only $(\bar{x}=10 \%$ difference $)$ than the $X_{D}+X_{H}$ formulation ( $\bar{x}=16 \%$ difference; Table 2$)$. All models predicted more biomass in 2006 than 2005, which is consistent with the increase in plant density.

\section{DISCUSSION}

\section{Multispecies Model}

The strength of our multispecies models to predict biomass for eight common cespitose grasses was consistent with that reported for trees (Singh 1986; Jenkins et al. 2003; Lambert et al. 2005) and shrubs (Buech and Rugg 1989) and supports the concept of a biomass-size relationship that scales across species within a life-form (Enquist 2002). The slope for the diameteronly multispecies model $(b=1.25)$ suggests that biomass will double $(100 \%$ increase) with only a $\sim 75 \%$ increase in diameter.

These results are consistent with previous work for grasses (Andariese and Covington 1986; Assaeed 1997; Guevara et al. 2002) and trees (Lambert et al. 2005), where there was little improvement in predictive strength when adding height to single-species or multispecies models that already contained diameter. The small improvement in predictive strength when adding grazing history to the model suggests that long-term change in biomass-size relationships are either unimportant or disappear within $2 \mathrm{yr}$ of grazing cessation (Petersen 1962; Trlica and Orodho 1989).

\section{Cautionary Notes}

Although our multispecies model for grasses generalizes across species and grazing histories, we caution that it may not perform as well in other locations. Significant intersite variation in biomass-size relationships has been noted for trees (Ares and Fownes 2000), shrubs (Buech and Rugg 1989), and grasses (Andariese and Covington 1986). For example, we found substantial differences in biomass estimates between our models and those developed in Argentina (Guevara et al. 2002) for cottontop and plain bristlegrass. For hypothetical populations of 20 plants (evenly distributed between $0.9-18 \mathrm{~cm}$ and $0.4-8 \mathrm{~cm}$ in diameter for cottontop and plains bristlegrass, respectively), our estimates for cottontop using the multispecies (1555 g) and single-species (1658 g) models were $60 \%$ and $73 \%$ greater, respectively, than the Argentine model (956 g), and estimates for plains bristlegrass using the multispecies $(563 \mathrm{~g}$ ) and singlespecies $(671 \mathrm{~g}$ ) models were $<10 \%$ and $>30 \%$ different than the Argentine model $(511 \mathrm{~g})$. Thus, caution should be exercised when extrapolating our allometric models to other locations.

We also caution that changes in population size structure may influence accuracy of predictions, especially when the regression slope $(b)$ differs between single-species and multispecies models. Slopes for cottontop $(b=1.25)$ and bush muhly $(b=1.20)$ single-species models were similar to the multispecies model $(b=1.25)$, and differences between single-species and multispecies biomass estimates for actual populations remained $\leq 10 \%$ even when the third decile size-class (4.1$6.0 \mathrm{~cm}$ in diameter) nearly doubled between 2005 and 2006 for cottontop, and there were large changes $(3.5-7.9 \%)$ in the first through third decile size-classes $(0.0-4.3 \mathrm{~cm})$ for bush muhly. In contrast, slopes for Lehmann's lovegrass $(b=1.43)$ and plains bristlegrass $(b=1.49)$ single-species models were steeper than the multispecies model, and the difference between singlespecies and multispecies biomass estimates increased from $<5 \%$ to $>20 \%$ for plains bristlegrass when contributions from the first decile size-class $(0.0-0.8 \mathrm{~cm})$ declined $(5.2 \%)$ between 2005 and 2006; and for Lehmann's lovegrass, the difference between model estimates decreased from $>25 \%$ to $<3 \%$ when contributions from the first decile size-class $(0.0-$ $0.8 \mathrm{~cm})$ increased $(3.3 \%)$ between 2005 and 2006 .

\section{IMPLICATIONS}

Multispecies allometry models provide a robust, nondestructive method to estimate grass ANPP on semidesert rangelands. Field-time efficiency will be maximized without sacrificing accuracy when using the parsimonious diameter-only multispecies model because only single, rapidly obtainable measures of basal diameter will be needed. Furthermore, species identification and grazing history will not be needed. 


\section{ACKNOWLEDGMENTS}

M. Castillo, E. Hurd, F. Mashiri, J. Mudd, J. Root, and C. Tewksbury helped obtain and process samples, and C. McMurtry provided field and logistical assistance.

\section{LITERATURE CITED}

Andariese, S. W., and W. W. Covington. 1986. Biomass estimation for four common grass species in northern Arizona ponderosa pine. Journal of Range Management 39:472-473.

ARES, A., AND J. H. Fownes. 2000. Comparisons between generalized and specific tree biomass functions as applied to tropical ash (Fraxinus uhdeI). New Forests 20:277-286.

AssaeEd, A. M. 1997. Estimation of biomass and utilization of three perennial range grasses in Saudi Arabia. Journal of Arid Environments 36:103-111.

BASKeRVILle, G. I. 1972. Use of logarithmic regression in estimation of plant biomass. Canadian Journal of Forestry 2:49-53.

Breckenfeld, D. J., And D. Robinett. 2003. Soil and ecological sites of the Santa Rita Experimental Range. In: M. P. McClaran, P. F. Ffolliott, and C. B. Edminster [TECH. COORDS.]. Santa Rita Experimental Range: 100 years (1903 to 2003) of accomplishments and contributions; conference proceedings; 30 October-1 November 2003; Tucson, AZ, USA. Proc. RMRS-P-30. Ogden, UT, USA: US Department of Agriculture, Forest Service, Rocky Mountain Research Station. p. 157-163.

Buech, R. R., And D. J. Rugg. 1989. Biomass relations of shrub components and their generality. Forest Ecology and Management 26:257-264.

CABLE, D. R. 1975. Influence of precipitation on perennial grass production in the semidesert Southwest. Ecology 56:981-986.

EnquIST, B. J. 2002. Universal scaling in tree and vascular plant allometry: toward a general quantitative theory linking plant form and function from cell to ecosystems. Tree Physiology 22:1045-1064.

Gayon, J. 2000. History of the concept of allometry. American Zoologist 40: 748-758.

Guevara, J. C., J. M. Gonnet, and 0. R. Estevez. 2002. Biomass estimation for native perennial grasses in the plain of Mendoza, Argentina. Journal of Arid Environments 50:613-619.
Jenkins, J. C., D. C. Chojnacky, L. S. Heath, and R. A. Birdsey. 2003. Nationalscale biomass estimators for United States tree species. Forest Science 49:12-35.

Johnson, P. S., C. L. Johnson, ANd N. E. West. 1988. Estimation of phytomass for ungrazed crested wheatgrass plants using allometric equations. Journal of Range Management 41:421-425.

Kotanen, P. M., And J. Bergelson. 2000. Effects of simulated grazing on different genotypes of Bouteloua gracilis: how important is morphology? Oecologia 123:66-74.

Lambert, M. C., C. H. Ung, and F. Raulier. 2005. Canadian national tree aboveground biomass equations. Canadian Journal of Forestry Research 35:1996-2018.

Mashiri, F. E., M. P. McClaran, and J. S. Fehmi. 2008. Short- and long-term vegetation change in relation to grazing systems, precipitation, and mesquite cover. Rangeland Ecology and Management 61:368-379.

McClaran, M. P., and D. L. Angell. 2006. Long-term vegetation responses to mesquite removal in desert grassland. Journal of Arid Environments 66:686-697.

Northup, B. K., S. F. Zitzer, S. Archer, C. R. McMurtry, and T. W. Boutton. 2005. Above-ground biomass and carbon and nitrogen content of woody species in a subtropical thornscrub parkland. Journal of Arid Environments 62: 23-43.

Peterson, R. A. 1962. Factors affecting resistance to heavy grazing in needle-andthread grass. Journal of Range Management 15:183-189.

Sala, O. E., And A. T. Austin. 2000. Methods of estimating aboveground net primary productivity. In: 0. E. Sala, R. B. Jackson, H. A. Mooney, and R. W. Howarth [EDS.]. Methods in ecosystem science. New York, NY, USA: Springer. p. 31-43.

Sall, J., L. Creighton, and A. Lehman. 2005. JMP start statistics. Belmont, CA, USA: Duxbury. $580 p$

Scurlock, J. M. 0., K. Johnson, and R. J. OLson. 2002. Estimating net primary productivity from grassland biomass dynamics measurements. Global Change Biology 8:736-753.

Singh, T. 1986. Generalizing biomass equations for the boreal forest region of west-central Canada. Forest Ecology and Management 17:97-107.

TrLICA, M. J., AND A. B. ORoDHo. 1989. Effects of protection from grazing on morphological and chemical characteristics of Indian ricegrass, Oryzopsis hymenoides. Oikos 56:299-308. 